\begin{tabular}{|c|c|}
\hline $\begin{array}{c}\text { ASIAN SOCIAL WORK } \\
\text { JOURAL } \\
\text { (ASW) }\end{array}$ & Asian Social Work Journal (ASWJ) \\
& Volume 4, Issue 2, March 2019 \\
& e-ISSN : 0128-1577 \\
& Journal home page: \\
& www.msocialwork.com \\
\hline
\end{tabular}

\title{
Burnout of Parent Who Have Children with Cerebral Palsy Disability in Bandung City
}

\author{
Enkeu Agiati ${ }^{1}$, Enung Huripah ${ }^{1}$ \\ ${ }^{1}$ Sekolah Tinggi Kesejahteraan Sosial Bandung, Indonesia \\ Corrrespondence: Enkeu Agiati (agiatienkeu@yahoo.co.id)
}

\begin{abstract}
Burnout refers to feelings of physical, emotional and mental exhaustion of parents who have children with cerebral palsy disabilities. The purpose of the research was to examine: 1) Characteristics of the subject, 2) Feelings of physical fatigue, 3) Feelings of emotional fatigue, and 4) Feelings of mental fatigue. The method used was descriptive qualitative method. The data sources used are primary and secondary data sources. The technique of determining the informants used was purposive. Data collection techniques used were in-depth interviews, participatory observation, and documentation study. The criteria for checking data validity used credibility test, transferability test, dependability test, conformbility test with the technique of extending participation, observation persistence, and triangulation. Data analysis techniques used qualitative data analysis techniques. The results showed that parents who have cerebral palsy children experience burnout characterized by feelings of physical, emotional and mental fatigue. However, feelings of physical and emotional exhaustion can still be overcome properly, only the feeling of mental fatigue cannot be overcome.
\end{abstract}

Key words: burnout, parent, children with disability, cerebral palsy

\section{Introduction}

Children with disabilities (CWD) are children who experience limitations both physically, intellectually, mentally and sensory. These limitations make CWD having difficulty in carrying out daily activities, such as: learning, playing, interacting with peers, and establishing relationships with people around them. These difficulties result in CWD requiring special care and parenting to deal with the problems they have experienced, including intellectual disability.

Children with Cerebral Palsy (CWCP) are a collection of conditions that affect muscles and nerves, common in infants and children. Cerebral palsy is not inherited but appears early in life. The CP child has the right to grow and develop as other children. Law Number: 08 of 2016 concerning Disabled Persons, explains; the right of every person with disabilities including the right of CWCP to obtain equal opportunities in every aspect such as the right to life, growth, protection and participation. Even though the CWD has been guaranteed by the Act, in reality CW CP still faces obstacles and limitations. The limitation experienced by CWCP is limited mobility and access to all basic social services needed by CWCP. These limitations require special attention to problem solving, because with these limitations will interfere with CWCP activities in activities. Therefore the government is specifically in providing services for CWCP and parents in CWCP care so that children can obtain their rights and basic needs in developing the special potential that exists in them.. CWCP has special needs and special care. However, the primary responsibility for meeting the needs and special care for CWCP lies 
with parents, especially CWD mothers, so parents are required to have high patience, good physical and mental health, and special skills in carrying out tasks in the care of cerebral palsy. Parental skills here especially parenting skills for CWCP are based on full attention and social support, so that children can grow and develop according to their potential.

Parenting, care and social support for CWCP is certainly not the same as children in general, because CWCP requires special attention and skills. ways to get closer, communicate, interact, to ways to convey compassion differently. Therefore parents, especially mothers, are required to have special parenting skills in terms of caring for children who experience the disability of children with cerebral palsy, so that the process of child development goes according to the task of developing CWCP.

Many parents experience difficulties in caring for and caring for children with CP disabilities, so that many parents experience burnout and cause stress. Stress problems can cause changes in attitudes and behavior to be negative, so that it affects both the child and the parents of the child and there are likely to be a variety of serious problems. Parents will cause physical, emotional and psychological fatigue that in a certain period of time results in burnout.

Burnout is a long-term work stress reaction that occurs mainly in parents, professionals who work in the humanitarian service sector such as social workers, teachers, nurses, police and prison guards. Burnout is caused by several conditions, including the weight of workload (work overload), role conflict and role ambiguity, the complexity of the problems faced (Cherniss in Sujipto 2001). Burnout is a very important subject because the impact is very extraordinary hit every person or worker in all institutions, including the service provider institutions. Burnout is the result of a series of processes that occur in humans, where the process will later have an impact on physical, emotional and mental fatigue.

The negative impact that can be caused by work burnout can be in the form of chaos both in management and execution of work, disrupting normal work activities and lowering the level of productivity. If the burnout experienced by parents reaches a peak then at this point if the workload is added, it tends not to result in improved work, then if burnout is experienced then the performance of a person (parent) will decrease, so that it will affect the care and child and this condition will cause parents to lose the ability to control their behavior.

Based on the description, it is very interesting to conduct research on the problem of burnout that occurs in parents, especially mothers who have cerebral palsy PPE. It is hoped that this research will be beneficial for all parties and stakeholders related to family resilience in CWD care and can be used as a basis for policy and program preparation for CWD or CWD parents who experience burnout.

The research problems are "How Burnout Parents of Children with Disabilities CP?" Then the problem formulation is focused on: 1) How do the characteristics of the subject?, 2) What is the feeling physically exhausted the subject in child care ?, 3) How the emotional exhaustion subject in parenting ?, and 4) What is the feeling of the subject's mental fatigue? The purpose of this research is to explore about: 1) the characteristics of the subject, 2) the feeling of physical fatigue of the subject in parenting? 3 ) the feeling of emotional exhaustion of the subject in parenting?

Burnout according to Pines and Aronson (in Suharto, 2007: 50) is a state of mind accompanied by a variety of symptoms such as emotional exhaustion, physical, mental, and feelings of despair and loss of morale and even the spirit of life. Freudenberger (in Suharto, 2007: 51) explains that:

The symptoms of burnout usually include cynical and negative attitudes, behaviors in thinking that often lead to dead ends that are closed to change or innovation. People who experience burnout are usually cynical looking at people as people who deserve problems because of their own mistakes which will ultimately reduce the quality of services provided.

Burnout arises from a person's internal condition which is supported by environmental factors such as protracted pressure. Employees feel burnout because of the conditions of the work environment which 
implies that what the employee has done is useless, useless, and not valued and there are rigid, inflexible procedures or rules so that employees feel trapped in an unfair system. This situation can be known through employee perceptions of the psychological work environment.

Someone who experiences Burnout because of his daily routine, individuals who experience burnout will have an impact on the psychological, physical and mental state of the individual, consequently the quality of the individual's work will decrease as well as its performance. Therefore burnout greatly affects the life patterns of workers who in their daily lives do the same work routine.

Pines and Aronson in Firdaus, (2005) say that people affected by burnout will experience physical, mental, and emotional fatigue: 1) physical exhaustion, which is physical exhaustion and physical energy fatigue, 2) emotional exhaustion, which is an individual's fatigue associated with personal feelings characterized by feelings of helplessness and depression, 3) mental exhaustion, which is a condition of fatigue in the individual associated with low self-esteem and depersonalization.

Factors that affect burnout, according to Suharto (2009: 55) are: 1) Stress, burnout is closely related to stress. Burnout is one reaction to a stressful situation. Furthermore, the factors that cause stress according to Hani Handoko (2014: 201) are divided into 2 parts, namely stress caused by work environment factors and factors outside the work environment and 2) Structural factors, burnout is also caused by events or factors structural factors. Furthermore, Edelwich in Zastrow (2014) identified several structural factors related to work that resulted in burnout, namely too many hours of work, dead-end career or not developing, too much work to be done, not fulfilling job training, not valued by clients, not valued by supervisors, not properly paid, no support in making important decisions, no authority, systems not responsive to client needs, poor work conditions and situations, discrimination based on gender.

According to Pines \& Aronson in Rahman (2007: 220) classifying general characteristics of burnout, namely: 1) Physical pain characterized as headache, fever, back pain, tension in the neck and shoulder muscles, frequent colds, insomnia, fatigue chronic, 2) Emotional fatigue is characterized as boredom, irritability, cynicism, anger, anxiety, hopelessness, sadness, stress, helplessness, and 3) Mental fatigue is characterized as indifferent to the environment, negative attitudes toward others, low self-concept, despair with life, feeling worthless.

Law No. 35 of 2014 concerning Child Protection explains that children are anyone who is not 18 years old and is still in the womb. Disabled Children (CWD) is someone who is 18 years and under who has a physical or mental disorder that can interfere or is an obstacle and obstacle for him to perform his physical, spiritual and social functions properly, consisting of children with physical disabilities , children with mental disabilities and children with physical and mental disabilities. Variety of disabilities in children include: 1) physical disability; including one of them is Cerebral Palsy (CP).

The factor that causes children to experience CP disability is because of an injury to the part of the brain that controls the ability to use muscles. Cerebral means to connect with the brain. Palsy means weakness or difficulty using muscles. There are several other causes that can cause a child to experience cerebral palsy: 1) the mother has an injury during pregnancy, or the baby is injured during labor or early childhood, 2) Does not get enough oxygen during or after birth, 3) Infection ( for example German measles) which transmits from mother to baby, and 4) serious infection in newborns.

Social Work Practice Interventions in the Problem of Burnout, Zastrow (in Suharto: 2014; 24) that social work is a professional activity to help individuals, groups and communities improve or improve their capacity to function socially and create conducive conditions for society to achieve that goal. Social work in the intervention of social problems is directed at efforts to help and help individuals, families, groups and communities to be able to function socially according to their status and role in people's lives.

Allen Pincus and Anne Minahan expressed their opinions on the objectives of social work that were translated by Soetarso (2014: 5) as follows: 1) Increasing the ability of people to deal with life's tasks 
and the ability to solve the problems they faced, 2) Linking people with system that can provide resources, services, opportunities needed, 3) Improve the ability to implement the system effectively and in a humanitarian manner, and 4) Provide contributions to change, improvement and development of policies and social legislation.

\section{Method}

The method used in this research is a qualitative research method. Qualitative research methods according to Lexy J. Moleong (2007: 6):

Qualitative research is research that intends to understand the phenomenon of what is experienced by the subject of research such as behavior, perceptions, motivations, actions, etc., holistically and by means of descriptions in the form of words and language, in a special natural context and by utilizing various natural methods

Qualitative research methods aim to provide meaning to the complete phenomenon of the individual and the behavior observed by the researcher to the research target. The research objectives observed were CWCP parents who experienced burnout to look for facts related to burnout experienced by these parents. In this study to avoid misinterpretation of the concepts or terms used in lecture research an explanation of terms was made: 1) burnout is a feeling of physical fatigue, emotional fatigue and psychological fatigue experienced by parents (mothers) of CWCP 2) Parents are biological mothers of CWCP who experience burnout in the care of their children.

Sources of data used in this study are: 1) The source of primary data is the source of data obtained directly from the research subject, namely the mother of CWCP through in-depth interviews and participant observation. Determination of subjects in this study was conducted purposively. The purposive technique is taking subjects based on criteria including: 1) Mothers who have CWCP, 2) CWCP aged 7-14 years, 3) have taken care of children at least 5 (five) years, and 4) CWD mothers who are subjects still have partners ( husband). The secondary data sources used were obtained by researchers through the study of documentation, books, research journals and observations of parenting activities against CWCP.

Data collection techniques used are: 1) In-depth Interview, 2). Observation of participation (participant observation); and 3) Documentation Study; Documentation study data collection techniques are techniques by studying the literature of the theories underlying the research, other data such as photos, recordings / case records. The data validity checking technique used is the credibility test, transferability test, dependability test, conformbility test with the technique of extending participation, perseverance observation, and triangulation. Data analysis techniques using analytical techniques used are qualitative data. The data analysis according to Lexy J. Moleong (2007: 6) used in this study are: 1) Data reduction is a sensitive thinking process that requires high intelligence, breadth and depth of insight. 2) Categorization is an attempt to sort out each unit into parts that have similarities. Each category is given the name 'label', and 3) Synthesis; means finding links between one category and another. Linkages of one category to another category are given names / labels again.

\section{Result and Discussion}

The subjects of this research were mothers of cerebral palsy PPE who experienced burnout, totaling 2 (two) people, namely Subject N and the subject "J". Subject N, 35 years old, has an undergraduate education, a variety of Islam, and comes from Cianjur, West Java, but since I was born I lived in Bandung. The subjects and two boys from their marriages and the youngest child (second) had a disability CP was able to take care and the subject "N" had cared for her child for 14 years. The second subject is "J", aged 37 has D3 education, is Muslim, and has cared for children for 7 years. The "J" 
subject originated from Garut, West Java and was domiciled in Bandung since high school, and had one child who had CP disability since birth.

\section{Subject Physical Fatigue Feelings}

The subject "N" shows the feeling of physical fatigue caused by the behavior of their child which is very difficult to regulate, causing " $\mathrm{N}$ " to suffer from pain in the back. Especially because "N" has to take care of two children, and doing their own housework makes " $\mathrm{N}$ " very vulnerable to suffering from pain, including back pain, aches, and left headache.

The "J" subject who said he experienced physical fatigue caused the subject "J" to experience pain, so he had to get hospital treatment for several days. The "J" subject says that:

I often feel headaches when my child is fussy, so I feel exhausted).

The "J" activity in nurturing "E" children makes the immune system of the "J" subject weak, so that it is susceptible to disease, "J" has experienced "migraine" pain and "typhoid" symptoms which require hospital stays. Daily activities that are draining and not balanced by a break which is enough to cause "J" to fall ill. If the "J" activity continues like this then "J" has the potential to experience hypertension.

The "N" subject also feels physical fatigue due to the activity of caring for and caring for his child. This is "N" as follows :

"I felt a headache and waist, because my child was still like a child, especially if the defecation child was still unable to help himself, so I had to pace.

The subject "N" has a headache and waist. This is caused by the behavior of their children who often make busy " $\mathrm{N}$ " have to run to keep children safe and avoid accidents. A great sense of affection for her child makes "N" always look after and help her child sometimes even excessive. The statements of the two subjects indicated that both felt pain in some parts of the body, pain that was physically tiring and made both subjects burnout due to the limitations and behavior of children who are sometimes unruly, making it difficult for both subjects to treat children.

The reaction of the two subjects when they felt physical fatigue had an effect on their desire to carry out their activities. This has an impact on the less optimal subject in carrying out other work caused by the majority of the energy of the two subjects used to care for and care for their children who experience intellectual disbility, as expressed by the following subject "J":

I take care of children with intellectual disabilities who have to nibble and give attention, it must be very tired, but because this has become a necessity it doesn't feel tired, but it's tiring).

Based on the description of the subject "J", the subject " $\mathrm{J}$ " felt tired and tired of this condition caused by activities in caring for and caring for PPE CP especially "J" must continue to feel this condition so it would make " $\mathrm{j}$ " feel bored and could ignore the task as a mother and wife, so that the subject never keeps his own body condition. If "J" also continues to ignore physical fatigue, it is very potential " $\mathrm{J}$ " to get sick. The same is true for the subject "N" who reacts to his physical fatigue by realizing that if a job as a mother of CWCP certainly risks one of them is the risk of experiencing physical fatigue. As the subject "N" follows:

It can't be helped, this has become a risk, I must be tired of taking care of my children, especially when I do my own housework because I don't have a maid. 
Explanation of the two subjects shows that the subject is accustomed to facing physical fatigue that is experienced everyday, so that both subjects still have to pay attention to their health conditions, especially the subject must try to overcome physical fatigue by resting with and using the smallest time to be able to be other, as stated the following subject "N":

Even though I got sick, I rested at home and took medicine, if I rarely drank, but only if my condition was very weak, I took medicine.

Based on this explanation, the effort " $\mathrm{N}$ " to overcome physical fatigue is to rest at home. "N" very rarely goes to the doctor or to the health center to check his health, even "N", if the pain has been too much new "N" take medication. The same thing was stated by "J" who tried to overcome his physical fatigue by resting at home, as follows:

I just rested at home, resting hours sitting on the terrace.

The statement explains the effort "J" to overcome physical fatigue is to rest at home, because by resting, the body will come back refreshed and ready to move again or sekear sitting on the terrace at recess. This aims to re-prime his physical condition so that he can take care of his children.

\section{Feelings of Emotional Fatigue}

The emotional feeling of the subject felt by the two subjects was different. The subject "N" feels emotional fatigue by showing irritation to his child as he follows:

I sometimes get tired so much ... I used to have my veil pulled by a child until I screamed, finally I was helped by a neighbor maybe because at that time I seemed to be unbearable because my son's request was not followed.

The "N" subject often receives rude and disrespectful treatment from his son's response, which makes him annoyed. Actually "N" is very understandable with the condition of his child who has intellectual disability, so the subject does not fully understand what is being done. It's just that when the behavior of his son who hurt him, "N" can no longer understand and eventually becomes "annoyed". Likewise, everything with the subject "J" also states if the child applies fussing, rude, and disrespectful, as he says the following:

When I said: 'Do not make me feel bad and do not be spoiled, if spoiled and made sad I will tell your father, my child even more fussy, beat me, angry. This makes me angry and emotional to the child.

The "J" subject really understands the condition of his child who is very unruly, so that the subject "J" sometimes feels annoyed. This is caused by advice that his child never listens to and even opposes. Meanwhile the subject "J" also feels the same thing, as follows:

There is a feeling of annoyance, but it all comes back to me, only sometimes as a human being when he has a heavy burden that he is innate and wants to be angry. However, I like to remember quickly that my child needs special attention).

Both subjects have felt annoyed with their own children and this situation is caused by the behavior of their children often asking for this, realizing the limitations of their children sometimes only at a glance do not fully understand the actions that their child requests. Parents who are the subject of this study face emotional fatigue showing the same reaction, namely realizing about the risk as a result of their child and having children with CP instability. Stable will make his child less comfortable with him. 
The results of interviews with both subjects in overcoming feelings of emotional exhaustion, both subjects tried to overcome them by making coping strategies, so that emotional fatigue felt diminished even for a moment. However, as parents, they understand very well about the condition of their children who have limitations, forcing both subjects to care for and educate their children with extras.

\section{Feelings of Mental Fatigue}

The subject's feelings while caring for and caring for children with CP disabilities vary, as well as the feeling of mental fatigue experienced by the subject of the research. As explained by the subject "N" about the feeling of mental fatigue she felt during parenting, as he revealed:

If my child is fussy and asks to be carried here and there, I only stroked my chest while saying wait.

The subject "N" even though he often feels helpless as a mother is caused by his child's behavior that he cannot control anymore, making him unable to do anything other than reprimand him verbally. In line with "N", the subject "J" also feels helplessness, as follows:

When I'm tired until I'm helpless, sometimes I take the child out of the house for a while so that I don't feel bored, even though I feel very tired.

The statement shows that the subject "J" sometimes feels helpless when facing a child who is acting out of bounds. This is because fatigue and fatigue which are the causes of "J" helplessness face the behavior of their children. But as "J" parents always have a way to deal with a situation like this, namely by inviting their children to play. Meanwhile the feeling of mental fatigue such as feeling not valued is felt by "N" and overcome by " $\mathrm{N}$ " as revealed in the following:

I am used to dealing with children and feeling tired, dizzy, especially if the child moves to and fro I feel how ..., but I am patient and my child is taken to play in a comfortable place).

The "N" reaction is very human when he feels tired when a fussy child " $\mathrm{N}$ " feels saturated and dizzy, but this is overcome by "N" with patience and spaciousness. "N" always strives to be able to manage itself, so that it is not carried away by situations that make it burdened. The efforts made by " $\mathrm{N}$ " are always accepting and always grateful, by the way that " $\mathrm{N}$ " is done can overcome mental fatigue experienced and " $\mathrm{N}$ " overcome mental fatigue that is by managing oneself, so that not doing something that is not appropriate to do.

\section{Discussion}

Burnout (Saturation) is a physical, emotional, and mental condition that is very dropping caused by a very demanding work situation in the long run (Muslihudin, 2009). Based on the results of the study obtained subjects who experienced burnout. The Burnout theory is a process of emotional physical fatigue, a feeling of mental fatigue that is thought to occur due to stress factors related to work. Burnout can also be due to monotonous or non-varied work, unclear work tasks, poor work control, dysfunctional work environment, and extreme activity (overload). More and more additional tasks must be done by mothers who have children with cerebral palsy. Therefore, the greater the burden that must be borne by the parents, the more severe the burden of the impact on parents and this will cause burnout.

Burnout which is indicated by feelings of physical fatigue, emotional fatigue, and mental fatigue. The physical fatigue of both subjects was shown to be unable to carry out activities, feeling sore and aching muscle joints. This condition results in not being able to sleep well, the heartbeat beating fast. Feelings of emotional exhaustion appear in several symptoms, such as lack of energy for activities, loss of caring, feeling, trust, interest, and enthusiasm. Efforts to overcome the imbalance between the demands 
and capabilities of the subject to overcome emotional fatigue. Whereas mental fatigue decreases interest and is not effective when doing work.

The results of the research showed that the parents of research subjects experienced emotional fatigue. This can be seen from the statement of the subject who said he was angry, easily offended, and unable to compensate for the difficulty in caring for and caring for his child, because the subject was lazy to do other work, making it easier to take non-constructive actions.

Emotional exhaustion is the core of burnout syndrome. Parents are very emotionally involved and feel "overwhelmed" and the consequences in caring for PPE are felt to drain energy sources, giving rise to feelings of frustration, despair, sadness, helplessness, and pressure and lack of interest in working. When someone experiences exhaustion, they feel the energy is drained and empty squeeze cannot be overcome.

The results of this research also showed parents experience emotional fatigue. This can be seen from the statement of the two subjects, that the subject complained of pain, fatigue, fatigue is a symptom that can lead to illness, in the form of physical, psychological or a combination of both. Similarly, the two subjects experience mental fatigue, mental fatigue (fatigue), is a condition where the body and soul feel tired not just tired, but lethargic and lackluster, describing physical and / or mental states becoming tired and weak. Both subjects despite experiencing mental fatigue but realized that this condition is a risk of having children with cerebral palsy disability and if the subject is mentally exhausted, they overcome it in a strategic way.

\section{Conclusions}

Based on the results of the research it can be concluded that the burnout aspects, namely physical fatigue, emotional fatigue, and mental fatigue. The burnout aspect affects the subject in caring for and caring for his child who has intellectual disability. Physical fatigue experienced by both subjects includes pain, drained energy and pain in certain parts of the body. This is due to the behavior of their children who often run around and behave in a way that is harmful to their children, such as carrying sharp objects to be put on their classmates, so that parents are always focused on paying attention to their children's behavior. However, both subjects managed to manage feelings of physical fatigue, so as not to interfere with the activities and concentration of the subject of watching and caring for children.

Emotional fatigue was also felt by the two subjects, the subject felt fatigue with feelings of irritability, and despair, and often irritated. This is caused by the behavior of CWD that is very difficult to manage, so repeated advice must be given so that the child wants to obey. Advice is given so that the CWD understands which actions can be carried out and what actions should not be taken. Emotional fatigue experienced by the subject is not disturbing, because the subject is able to overcome his emotional problems, so he can take care of his child properly. Efforts made by parents to overcome emotional fatigue are by inviting their children to play, sing, and dance together, so that the atmosphere becomes cheerful.

Meanwhile, mental fatigue experienced by parents still cannot be dealt with properly, so it has the potential to disrupt children's learning activities because parents have feelings of helplessness, pessimism, and feelings not denied by their children. This problem requires an effort to be addressed immediately so that the child behaves according to the rules that should be right. Efforts made by parents to overcome the problem of mental fatigue have actually been done, except that these efforts are only limited to surrender to God alone without real behavior, so that it is not fully optimal. Therefore the problem of mental fatigue requires a way out so that parents can carry out tasks and functions as well as the duties and functions of parents.

Both subjects still have great hopes for their children even though the child has limitations. This expectation includes the desire for their children to be able to live independently, to grow up, so as not 
to bother both parents or their families, but also hope that their children can be accepted in the community and not get discriminatory treatment, and be able to carry out activity of daily living.

\section{Recommendations}

Based on the description, it can be concluded that the problem of saturation (burnout) is the most important thing to be addressed immediately. Therefore the program was offered "Outbound Activities for parents who have cerebral palsy PPE in the Open Nature" Hopefully the program felt a feeling of physical, emotional fatigue and feelings of mental fatigue experienced by parents could decrease, so parents could carry out their duties and roles in caring for and care for CWD. Besides that, to implement this program it is recommended that there should be cooperation with: 1) People who care about CWD cerebral palsy, so that parents get social support, 2) Foundations, Foundations as owners of SLB-C are expected to contribute actively in learning activities. Contributions that can be made include: a) allocating school funds for outdoor outbound needs, b) making the outbound program an annual school agenda that must be implemented.

\section{References}

Ahola, Kirsi. (2007). Occupational Burnout and Health. Helsinki: YampereenYliopistopaino Oy Juvenes Print.

Arief Kustian (2013). Burnout Pekerja Sosial dalam Melayani Pasien Psikotik di Rumah Sakit Jiwa Provinsi Jawa Barat.

Bakker, Arnold, B., Demerouti, Evangelia (2007). The Job Demands-Resources model: state of the art. Journal of Managerial Psychology, 22(3), 309-328.

Bandi Delphie, (2010). Perkembangan Anak Tunagrahita Cetakan kesatu Bandung:Refika Aditama.

Dubois, Karla KM, (2014). Social Work An Empowering Profession. New York: Pearson Education Inc.

Edi Suharto, (2009). Pekerjaan Sosial di Dunia Industri. Cetakan Kedua. Bandung: Alfabeta.

Eka Danta Jaya G. (2005). Burnout Pada Karyawan Ditinjau Dari Locus Of Control Internal Dan Eksternal Di Biro Rektor Universitas Sumatera Utara (USU) Medan.

Gunarsa, S.D dan Gunarsa Y.S.D. 2008. Psikologi Perkembangan Anak dan Remaja. Jakarta : Gunung Mulia.

Hardynansyah (2015). Burnout Pengasuh Penyandang Disabilitas Mental di PSBG Ciung Wanara Bogor.

Katarini, Nikki Rasuna (2011).Burnout Pada Karyawan Ditinjau Dari Persepsi Budaya Organisasi Dan Motivasi Intrinsik Di PT. Krakatau Steel.

Kurniatyas (2011). Analisis Pengaruh Dukungan Sosial Keluarga Terhadap Burnout Pada Perawat Kesehatan Di Rumah Sakit Jiwa Prof. Dr. Soerojo Magelang.

Lailani, Fereshti (2012). Burnout Pada Perawat Ditinjau Dari Efikasi Diri Dan Dukungan Sosial.

Lexy J.Moleong, (2012). Metodologi Penelitian Kualitatif. Cetakan Kelima puluh. Bandung:Rosda.

Mahlmeister. (2003). Burnout Of Employe. Amerika : ISH.

Rahman Ulfiani 2007. Mengenal Burnout. Bandung : Lentera Pendidikan.

Rothman, Juliet C. (2003). Social Work Practice, Across Disability. New York: Pearson Education. Inc.

Undang-Undang Nomor 8 Tahun (2016). tentang Penyandang Disabilitas. 